
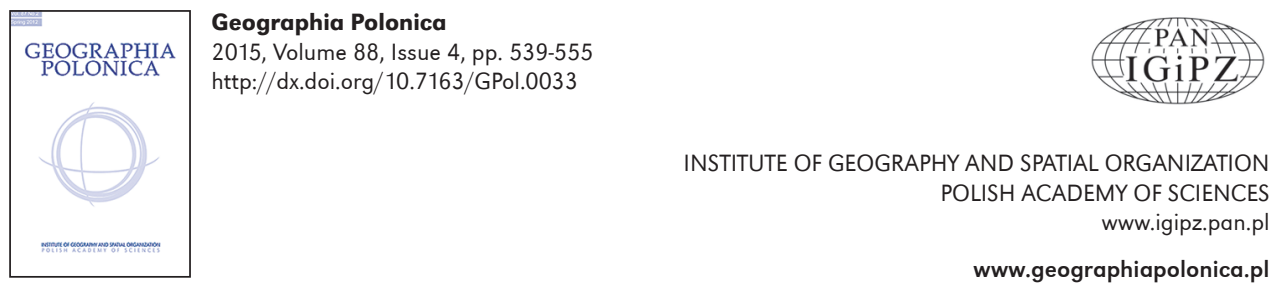

\title{
SPATIAL PATTERNS OF REGIONAL ECONOMIC DEVELOPMENT IN CENTRAL AND EASTERN EUROPEAN COUNTRIES
}

\author{
Maciej Smętkowski \\ Centre for European Regional and Local Studies (EUROREG) \\ University of Warsaw \\ Krakowskie Przedmieście 30, 00-927 Warsaw: Poland \\ e-mail: msmetkowski@uw.edu.pl
}

\begin{abstract}
The aim of the work described here has been to analyse the spatial patterns of regional economic development in the EU $10 \mathrm{New}$ Member States located in Central and Eastern Europe. Its first hypothesis suggests that regional convergence observed at macroregional level should lead to a decrease in spatial dependency at the NUTS3 level, i.e. to overall diffusion of development across particular countries. However, a second hypothesis claims that diffusion processes from national growth centres to their regional surroundings would be still quite limited and negligible. The latter hypothesis relates to a different pattern of diffusion in selected economic sectors that should largely explain the overall regional convergence process. To verify these hypotheses, the spatial autocorrelation method based on the Global Moran's I Statistic and Local Indicators of Spatial Association (LISA) has been applied for the period 1995-2009/2010, with special emphasis put on particular sub-periods reflecting different stages of the transformation process, EU membership and the recent economic crisis. Furthermore, the analysis covers values of GDP per capita both absolute and relativised (to the national averages), as well as structural differences that allow for the presentation of the diverse dimensions to regional economic growth.
\end{abstract}

\section{Key words}

regional convergence - spatial autocorrelation - economic development - Central and Eastern European countries

\section{Introduction}

The Central Eastern European countries (CEECs) joining the European Union in 2004 and 2007 are increasingly the objects of comparative analyses concerning regional development processes. Such growing interest stems from the specific characteristics of these countries arising from their postsocialist transformation and EU membership.

The systemic transformation of the New Member States should be regarded as largely 
finished, to the extent that their economies are coming to resemble those of the more developed Western European countries (Gorzelak 2008). However, some differences from one country to another can still be observed, as was demonstrated during the recent financial crisis, for example. Then, while many CEECs found themselves in the group of countries most severely affected, Poland emerged as the only EU country to show resilience in the face of the deteriorating external situation.

Upon their EU accession, the CEECs were included into the Cohesion Policy, a fact potentially having a strong bearing on the transformation of existing social and economic structures (cf. e.g. Bachtler \& Downes 2004; Bachtler \& McMaster 2008). The process of adaptation of national regional and spatial policies was also affected. While some countries based these policies on a traditional understanding of territorial cohesion - as an equal or similar level of development between individual regions on the one hand, and on the other - on a more modern approach emphasising the significance of functional ties between regions at different levels of development (cf. Gorzelak 2009; OECD 2010; Smętkowski 2013b). In the political dimension, the former of these approaches attempts to narrow the existing differences (often referred to as disparities) in the level of development, whereas the latter embraces the polarisation and diffusion model aiming to strengthen the functional ties between the core and the peripheral regions, thereby leading to their harmonious coexistence. Regardless of which of these models is adopted, the spatial range of spread effects and forms of diffusion of economic development is a particularly valid issue, and tackled in this paper.

Based on the earlier empirical research conducted in the CEECs (e.g. Petrakos 2001; Römich 2003; Ezcurra et al. 2007; Gorzelak \& Smętkowski 2010; Monastiriotis 2011; Próchniak 2011; Smętkowski \& Wójcik 2012), it can be concluded that there is an observable regional convergence in the level of development across the entire macroregion (both in absolute terms and as relativised by PPS), due to the catching-up processes taking place in the less-developed countries (Bulgaria, Romania and the Baltic states) as a result of their rapid growth, in some cases also reinforced by the appreciation of their national currencies. On the other hand, all these countries (except Latvia, where the income disparities across regions were particularly wide) are undergoing a process of regional divergence, mainly as a result of a rapid growth of large cities and a relative stagnation of the peripheral areas, mostly agricultural, while the situation of the industrial/ transition regions varies from one to another. Metropolises, especially the capital cities, have been the main beneficiaries of the transformation processes and EU accession. This reflects a number of factors, including the inflow of foreign capital on the one hand, and on the other the availability of a highly skilled workforce which has fostered the growth of endogenous entrepreneurship and innovation. As a consequence, their economic structures underwent a radical change, whereby the advanced services sector took the leading role, and the role of manufacturing activities was diminished considerably. In contrast, the remaining regions of the CEECs are struggling with two basic types of development barrier (Smętkowski 2013a). In the peripheral regions, a disadvantageous economic structure is the main problem, as manifested in very high rates of employment in agriculture. In parallel, traditional industrial regions are still suffering from the consequences of the collapse of their economic base, which produced structural unemployment and crippled their attractiveness for the inflow of new investments, as also affected by the still-unsatisfactory condition of the natural environment.

The previous research investigating regional convergence processes has usually sought to show the scale and dynamics of existing disparities, as well as factors underpinning them, with relatively little attention being paid to the relationships between the spread effects and their forms. The aim 
of the work detailed in this paper has thus been to search for spatial patterns of the regional development processes ${ }^{1}$ ongoing in the CEEC regions, with special emphasis placed on the scale and types of the diffusion processes.

The work has used Eurostat data on GDP per capita measured in EUR (relativised by country averages in some analyses), as well as GVA per capita in selected economic sectors. The time period for the analyses presented in this paper has been limited - in line with data availability - to the years 1995/2000-2009/2010, as divided into subperiods so that differences in the economic situation (notably the impact of the 2008 financial crisis) might be taken account of. The study has based itself on NUTS3 sub-regions, as these correspond to functional urban areas much more closely than the highly-internally-differentiated NUTS2 regions. In addition, the so-called separated cities were included into surrounding regions, with this relating to Poland's large cities, but also the capitals of the Czech Republic, Hungary, Romania, Bulgaria and Latvia. The aim of this move was to better capture the specific nature of real functional regions.

\section{Spread effects and spatial diffusion processes from the theoretical perspective}

It should first be noted that the notions of 'spread' and 'diffusion' are not identical. While the former derives from the economics and theories of convergence and polarised growth, the theory of diffusion is embedded in geographical research, in particular analyses of innovation expansion in space.

The notion of the spread of growth or economic development can be found in the theories of polarised development (cf. Grzeszczak 1999) originated by Perroux (1950). However, the latter analysed the process in question from a sectoral, not a spatial, perspective.

1 The GDP per capita indicator was used as a simplified measure of levels of economic development.
A spatialisation of the theory can be found in the work by Hirschman (1958), who assumed the existence of positive trickle-down effects being transmitted from the growth pole towards the peripheral region in line with complementarity, the flow of investments and the absorption of hidden unemployment. Negative polarisation effects were also envisaged, with these being thought to arise from competitive advantage, as well as the brain drain of well-qualified workers.

In contrast, in the light of the cumulative causation theory from Myrdal (1957), the notion of spread effects was used to explain the mechanisms underpinning spatial polarisation. According to this theory, development stimuli are transferred from the better-developed core regions to the peripheral areas in the form of capital investments. Such investments largely aim to satisfy the demand in the highly-developed areas, with this leading - should conditions prove favourable - to the transfer of technologies to the less-developed areas. However, under the life-cycle theory developed by Vernon (1966), such investments will mainly include products reaching the stage of maturity and standardisation, when competition depends on the costs of production. More technologically-advanced products will continue to be manufactured mainly in the core areas, with the effect thus being a consolidation of the competitive advantage of core areas over the periphery.

However, in line with neo-classical convergence theories, the transfer of capital on the one hand, and the movement of workers on the other, should lead to an equalisation of levels of development, in terms of per capita income, between the core and the peripheral regions ${ }^{2}$. Such a process is assumed

\footnotetext{
2 At the same time we should keep in mind the qualitative differences in the movement of capital and people between the core and peripheral areas. While the flow of capital investments from core to peripheral areas can mainly be assumed to apply in the medium- and low-tech sectors, flows of persons will usually involve the best-educated and most enterprising individuals, with the result that peripheral areas are 'brain-drained'.
} 
to be possible, owing to straightforward replication of solutions used in the better-developed regions, through the transfer of knowhow in the economic, social and institutional sphere. The new economic geography constituting an elaboration of these theories, also takes account of positive agglomeration effects, in addition to the costs of transport and mobility of production factors (Krugman 1991). The basic assumption is that income from economic activity will increase as its scale grows, in association with the agglomeration effects, as coupled with the mobility of production factors and a lack of barriers to international trade. The positive agglomeration effects arise from the interactions between enterprises.

What all this means is that, even if an assumption as regards the even distribution of production factors in space in the initial period is adopted, businesses will still be expected to cluster in selected locations after some time. Both the pace and final outcome of this process will depend on the role of transport costs and the scale of labour mobility. The significance of positive agglomeration effects is also emphasised in knowledge spillover theories that highlight local innovation potential considered to rest, not only upon R\&D expenditure, but also and above all on the presence of highly-skilled workers. It is such workers whose move to another workplace will disseminate new ideas in competing firms. The consequence of this kind of process is a very strong spatial concentration of the most innovative types of activity, in the so-called islands of innovation (Hilpert 1992).

All of this leaves the institutional environment in a position of cardinal importance, given the way it which it may foster the development of a given regional system (North 1991). The major role institutions have to play reflects their capacity to lower production costs - through the transfer of knowledge between the public and private sectors, and transaction costs - through a determination of the playing field for economic exchange, as well as control over compliance with adopted rules and regulations. As a result, various relationships other than the purely trade-related can develop between enterprises (Storper 1997). These untraded dependencies have strong regional roots, and can assume the form of conventions or informal habits and rules that are able to facilitate enterprises' activity in conditions of market uncertainty.

The above review of theories and concepts yields the following summary description of core and peripheral areas, which is accompanied by an evaluation of the convergence/ divergence processes resulting from changes in the latter (Tab. 1).

The fundamental advantage of the core areas over the periphery stems from the dominance of capital- and knowledge-intensive sectors typically enjoying high labour productivity and technological advancement in their economies. On the other hand, the low cost of labour in peripheral areas produces a competitive advantage not inducing increased productivity, especially given the limited capital resources and restricted access to high technologies. On the other hand, employees in the core areas have better qualifications, though in quite many cases labour market segmentation can be observed, into a creative class on the one hand (Florida 2002), and support workers on the other. In contrast, the peripheral regions are characterised by a high mobility of well-qualified workers, with relatively greater rootedness of workers lacking such qualifications, perhaps as a consequence of redistributive public policies. Another major difference is the functioning of the institutional environment supporting development, which is efficient and well-developed in the core areas, while having many weaknesses and shortfalls in the peripheral areas.

Differences of this kind ensure that economic convergence is possible where the typical attributes of peripheral areas are changed. This should be fostered through the attracting of capital- and knowledgeintensive, as opposed to labour-intensive, investments, with this triggering economic 
restructuring processes, increasing innovation and enhancing the technological level. High-quality jobs can be expected to appear as a consequence, this on the hand slowing down the brain drain from peripheral regions, while on the other hand increasing the mobility of less-skilled workers. One necessary precondition for any initiation of these processes is the presence of effective and efficient institutions tasked with fostering endogenous potential. Should the latter prove deficient in their operations, or seek instead to maintain the status quo, then their work will merely tend to petrify existing socio-economic structures.

The issue of diffusion, approached spatially, was mainly tackled by geographers investigating the transfer of innovation, initially Hägerstrand (1952, 1967). The latter's work prompted a number of studies addressing the temporal and spatial distribution of innovation, and ultimately yielding (e.g. in Gould 1969) a concept entailing fundamental subcategories of diffusion as:

- expansion or relocation (depending on changeability or stability in the number of components characterised by a given feature);

- contagious (wave) distribution or hierarchical filtering down the settlement system (depending on the spatial pattern of diffusion).

Diffusion of the first sub-category relates to changes in the location pattern typical for entities with specific characteristics. Thus expansion diffusion sees the number of such entities increase. In contrast, where the second sub-category of diffusion applies, the number of entities remains constant, with only their distribution in space being subject to change. One example might be the dissemination of an idea through society - a process that does not lead to changes in existing spatial structures. In the other case, diffusion is the result of relocation taking effect in the form of migration.

The second group takes account of the distance from the original source of innovation. In contagious diffusion, a spatial correlation exists between innovation and its sources. The function of physical distance, which can reduce the scale of diffusion processes,

Table 1. Convergence processes between the core and the periphery

a) A comparison of core and periphery characteristics

\begin{tabular}{|c|c|c|}
\hline & Core area & Peripheral area \\
\hline The economy & $\begin{array}{l}\text { Capital-intensive and knowledge-intensive } \\
\text { sectors } \\
\text { A high share of sectors of high labour produc- } \\
\text { tivity } \\
\text { A high level of technological advancement }\end{array}$ & $\begin{array}{l}\text { Labour-intensive sectors } \\
\text { A high share of sectors with high labour } \\
\text { productivity } \\
\text { A low level of technological advancement }\end{array}$ \\
\hline Employees & $\begin{array}{l}\text { Highly-qualified workers } \\
\text { Labour-market segmentation }\end{array}$ & $\begin{array}{l}\text { Mobility of highly-qualified workers } \\
\text { Strongly-rooted workers with low qualifications }\end{array}$ \\
\hline Institutions & Well-developed and efficient institutions & Weak and inefficient institutions \\
\hline
\end{tabular}

b) Changes in a peripheral area lead to:

\begin{tabular}{|l|l|l|}
\hline & \multicolumn{1}{|c|}{ Regional convergence } & \multicolumn{1}{c|}{ Regional divergence } \\
\hline Economy & $\begin{array}{l}\text { Capital- and knowledge-intensive investments } \\
\text { Economic restructuring } \\
\text { Transfer of new technologies }\end{array}$ & $\begin{array}{l}\text { Labour-intensive investments } \\
\text { No restructuring } \\
\text { Import of old technologies }\end{array}$ \\
Employees & $\begin{array}{l}\text { Strongly-rooted workers with high qualifications } \\
\text { High mobility of workers with low qualifications } \\
\text { Institutions }\end{array}$ & $\begin{array}{l}\text { Efficient institutions supporting innovation } \\
\text { Low mobility of workers with low qualifications }\end{array}$ \\
\end{tabular}


is assigned a prominent role in this process. Further transmission takes place in the form of a wave (Morill 1968). In stepwise diffusion, the hierarchical position of a given element in a set is of greater significance than the distance, in line with the idea that diffusion first takes place on a given level of the hierarchy, only later penetrating down to the lower levels. It should also be noted that, even with the very earliest attempts to formulate a typology of diffusion processes, the suggestion arose that the various types could probably occur side by side (Gould 1969; Łoboda 1983). Contemporarily, such a combination can be termed network (diversified) diffusion, with this deemed to derive from contagious and hierarchical diffusion combined, given that the transmission depends on both the location and the nodality of a given entity within the existing network of linkages.

\section{Assessment of spread effects and the diffusion of development processes using the spatial autocorrelation method}

\section{Research operationalisation}

Spatial autocorrelation is one of the methods used in the present study to measure diffusion. It is also employed quite frequently to analyse regional convergence processes (cf. e.g. ESPON 2005; Janc 2006; Curran 2009; Ressende 2012). Put simply, this method relates the intensity of the analysed phenomenon in a given unit to its surroundings, in order to show the regularity with which a given measure or indicator is distributed spatially (cf. e.g. Kopczewska 2006). To this end, matrices of spatial weightings for the linkages between analysed units are created, with account taken of the significance of the surroundings as dependent on distance. The Global Moran's I Statistic is used to measure autocorrelation, assuming values from -1 to 1 . Positive values indicate a tendency for the spatial clustering of units with similar values of a given measure or indicator, whereas a Moran's I value lower than 0 denotes proximity of units with different values, and hence a greater degree of dispersion and polycentricity of the analysed phenomenon. Moran's I close to 0 in turn indicates a random distribution of the phenomenon, i.e. spatial entropy.

In parallel, local indicators of spatial association (LISA) are used to show major clusters of given units, given that they identify the most important areas of both positive autocorrelation: $\mathrm{HH}$ (high-high, i.e. clusters of entities with high values) and LL (low-low, clusters of entities with low values), as well as negative autocorrelation: HL (high-low, that is, "hot spots'), and LH (low-high, i.e. 'cold spots'). It is in such a way that units characterised by adequately high or low values for a given measure or indicator are denoted in relation to their immediate surroundings.

Consideration also needs to be given to the border effect, whereby the neighbourhood system of outlying regions is disrupted by a border established arbitrarily that impacts upon indicator values. In the present study, the inclusion into the analysis of adjacent regions in neighbouring countries could also have altered the results obtained. However, extension of the area analysed would first have generated problems of interpretation, given the different permeabilities of the macroregion's external borders, and would second have impaired the comparability of the data used. Moreover, Moran's I Statistic is vulnerable to the number of selected neighbouring units. In identifying these, use may be made of the immediate neighbourhood (shared border) method, the $k$ nearest neighbour method or the maximum distance method. The present study employed the second of these, in line with an arbitrary assumption that the six closest units best reflect the existing system of NUTS3 statistical units in this part of Europe.

Empirical studies have found that changes in the global autocorrelation index are in line with economic convergence processes typically measured using the coefficient of variation for regional income (cf. e.g. Rey \& Montouri 1999). Convergence processes 
should be accompanied by a fall in the value of this index, and regional divergence by an increase, and hence by sigma convergence (Sala-i-Martin 1996). As regards the type of diffusion, the correlation between this index and Global Moran's I Statistic would be expected to afford interesting insights (Tab. 2). An increase in both of these values would be taken to signify growing spatial separation between the highly- and poorlydeveloped areas. Where the value of the coefficient of variation increases and the global correlation index decreases, it is rather hierarchical diffusion that can be anticipated, which is to say an emergence of hot spots in peripheral areas. As regards convergence measured using the coefficient of variation, an increase in Moran's index may suggest a contagious diffusion process taking place in the immediate vicinity of growth poles. However, if the values of both measures fall, it is the existence of varied diffusion processes taking both a contagious and a hierarchical form that is to be anticipated. spread of economic development processes to less-developed countries. The second hypothesis assumes that the spread effects from the national economic centres to their regional surroundings should be rather negligible owing to the abundant presence of transport, structural and other barriers, whereas the third proposes that the diffusion of economic activities should depend on the type of such activities, and might well take different forms in agriculture, industry and advanced business services.

\section{Macroregional vs. regional convergence}

In the researched period, an increasing level of affluence in the CEECs as measured in EUR was accompanied by convergence of the level of development across the macroregion (Tab. 3). In 1995, i.e. the initial period of the systemic transformation, the value of the coefficient of variation (standard deviation relative to the arithmetic mean) for

Table 2. Type of diffusion based on changes in the coefficient of variation and Global Moran's I Statistic

\begin{tabular}{|l|l|l|}
\hline & \multicolumn{1}{|c|}{ Coefficient of variation - increase } & \multicolumn{1}{c|}{ Coefficient of variation - decrease } \\
\hline Moran's I- increase & $\begin{array}{l}\text { Growing spatial autocorrelation leading } \\
\text { to divergence and lack of diffusion } \\
\text { Miminishing spatial autocorrelation leading } \\
\text { to divergence and hierarchical diffusion }\end{array}$ & $\begin{array}{l}\text { Growing spatial autocorrelation leading } \\
\text { to convergence and contagious diffusion } \\
\text { Diminishing spatial autocorrelation leading } \\
\text { to convergence and mixed hierarchical and } \\
\text { contagious diffusion }\end{array}$ \\
\hline
\end{tabular}

As a matter of course, the actual processes may be more complex than the model situations outlined above, implying that the type of diffusion determined using the matrix should then be verified using maps showing changes in spatial disparities as regards regional incomes.

A literature review and above-proposed methodology for the investigation of changes in the spatial structures gives rise to three main hypotheses. The first holds that regional convergence observable at the level of the CEEC macroregion should be accompanied by decreasing spatial autocorrelation at the development level, with this reflecting the
GDP per capita in all the CEECs was 0.67, which pointed to wide differences in incomes between the poorest (Bulgaria) and wealthiest (Slovenia) (EUR 6800 or a 1:6.7 ratio). By 2010, the value of that coefficient had fallen to 0.36 , notwithstanding a widening of the gap in absolute terms to EUR 12,600 (albeit now just a 1:3.6 ratio). This took place in the conditions of rapid economic growth among the poorer countries, as well as an appreciation of their national currencies in relation to the euro, which meant a 3.5-fold increase in the average per capita GDP in the countries of the (macro)region from EUR 2900 to EUR 10,000. 
The convergence observable between countries is also visible at the regional level, due to the correlation between the situation in the country and that in the regions. It should also be noted that this correlation can assume different values, depending on the analysis of growth expressed in EUR (A), and expressed in national currencies (B) (Tab. 4). Under the former approach, the correlation was high (and explained 68-72\% of the regional variance) in all the sub-periods except 2008-2009, which was a crisis year, in which the figure fell below 50\%. With the latter approach, there was a distinct decrease in the values for this correlation in the subsequent periods under analysis, from $62 \%\left(R^{2}\right)$ in $1995-2000$ to $8 \%$ in 2004 2008 , then followed to ca. $50 \%$ in 20082009.
Overall, the changes in regional incomes expressed in EUR (A) are seen to be strongly and quite stably dependent on the situation in the particular countries, which was partly a result of the appreciation or depreciation of the national currencies; while the correlation was much weaker in the approach using real growth of GDP in national currency (B). In the latter case, the position of regions was largely independent of that in particular countries, especially in the years 2000-2008, i.e. the period of the economic boom.

\section{Convergence and diffusion of economic development}

At the beginning of the analysed period, the spatial autocorrelation of regions' economic development level, expressed as the

Table 3. GDP per capita in the CEECs in the period 1995-2010 [EUR]

\begin{tabular}{|l|r|r|r|r|}
\hline \multicolumn{1}{|c|}{ Country } & 1995 & 2000 & 2005 & 2010 \\
\hline Bulgaria & 1,189 & 1,713 & 2,997 & 4,766 \\
Czech Republic & 4,278 & 6,203 & 10,237 & 14,303 \\
Estonia & 1,995 & 4,490 & 8,298 & 10,688 \\
Latvia & 1,517 & 3,541 & 5,605 & 8,023 \\
Lithuania & 1,413 & 3,545 & 6,122 & 8,293 \\
Hungary & 3,368 & 4,924 & 8,791 & 9,645 \\
Poland & 2,757 & 4,854 & 6,403 & 9,291 \\
Romania & 1,295 & 1,810 & 3,685 & 5,793 \\
Slovenia & 8,055 & 10,833 & 14,383 & 17,395 \\
Slovakia & 2,796 & 4,084 & 7,148 & 12,142 \\
Average (unweighted) & 2,866 & 4,600 & 7,367 & 10,034 \\
Standard deviation (SD) & 1,979 & 2,454 & 3,141 & 3,617 \\
Coefficient of variation (CV) & 0.69 & 0.53 & 0.43 & 0.36 \\
\hline
\end{tabular}

Source: on the basis of Eurostat data

Table 4. Correlations between country GDP growth and regional GDP growth among the CEECs

\begin{tabular}{|l|c|c|c|c|}
\hline \multirow{2}{*}{ Sub-periods } & \multicolumn{2}{|c|}{ Change of GDP per capita in EUR (\%) } & \multicolumn{2}{c|}{ Real change of GDP in national currency (\%) } \\
\cline { 2 - 5 } & $R$ & $R^{2}$ & $R$ & $R^{2}$ \\
\hline $1995-2000$ & 0.82 & 68.1 & 0.79 & 62.4 \\
$2000-2004$ & 0.85 & 72.2 & 0.54 & 29.5 \\
$2004-2008$ & 0.85 & 71.8 & 0.29 & 8.3 \\
$2008-2009$ & 0.69 & 48.3 & 0.70 & 48.6 \\
$1995-2009$ & 0.74 & 54.4 & 0.61 & 37.8 \\
\hline
\end{tabular}

Source: on the basis of Eurostat data 
Global Moran's I Statistic, was very strong (Fig. 1). This should be interpreted as a clear separation between regions situated in the more affluent countries, particularly in their western parts (in Slovenia, the Czech Republic, Hungary, Slovakia and Poland) and the regions situated in the Baltic states, Romania, Bulgaria and the eastern parts of the aforementioned countries (Fig. 2). On the one hand, this could be interpreted as proof of longue durée processes, and of many centuries of the contagious diffusion of urbanisation (Gorzelak \& Jałowiecki 2002). On the other, it could depend on the progress with transformation processes in the post-communist states, as first initiated in the Visegrád Group countries and Slovenia, as compared with the Baltic states, in which the heritage of the Soviet system and the need to rebuild sovereignty had to be grappled with; and Romania and Bulgaria, in which the transformation was delayed with the abandonment of attempts to introduce rapid economic reforms (Kołodko \& Tomkiewicz 2009).

In the period preceding accession to the EU (1995-2004), a relatively stable scale of regional disparities as measured by the coefficient of variation did not prevent the onset of a process of diffusion manifested in a decrease in the spatial autocorrelation index. This was due mainly to the rapid growth observable in the Baltic states, Romania and Bulgaria, and most especially in their capital-city regions. EU accession reinforced these trends, which were nevertheless associated with declining values for the coefficient of variation. This could be implicated as an example of contagious diffusion (e.g. via the transport corridor along route no. 1 in Romania, leading from Bucharest to the Hungarian border) and corroborated by an analysis of local indicators of spatial association (LISA) (Tab. 5). On this basis, the number of $\mathrm{HH}$ regions can be said to have increased by seven (to 33) as compared with 2000, while the number of $L L$ regions fell by 18 (to 48 ), and 'hot spots' made their appearance (as the capital-city regions of Sofia and Bucharest), along with 'cold spots' (in the shape of three
Polish sub-regions situated in the so-called shadow of large metropolises).

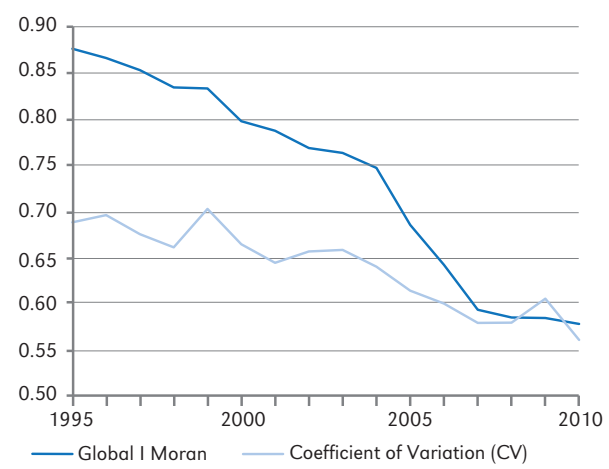

Figure 1. Changes in (A) global spatial autocorrelation and (B) sigma convergence for regional GDP per capita in EUR in the CEECs in the years 1995-2010*

* the higher the value of $(A)$, and the stronger the spatial dependency $(B)$, the greater the polarisation of regional incomes

Source: on the basis of Eurostat data

These trends did not change until the advent of the 2008 financial crisis. Interestingly, the earlier economic slowdown during the 1998 Russian crisis produced a similar effect, albeit on a smaller scale. At this stage, this phenomenon is hard to interpret, due to the chaotic nature of crisis phenomena disturbing the long-term trends.

It should be noted in conclusion that an east-west-related division of the CEE countries and their regions into the betterdeveloped and the less-developed still exists. To add to the picture, a considerable degree of polycentricity of the settlement system across the macroregion is to be be observed (see also Smętkowski \& Wójcik 2013).

\section{Diffusion of economic development from core regions}

The spatial autocorrelation revealed in the approach analysing increased regional income as (a) real, or (b) relative to the national average, is rather varied (Fig. 3). In the first approach, there was a visible rapid fall in 


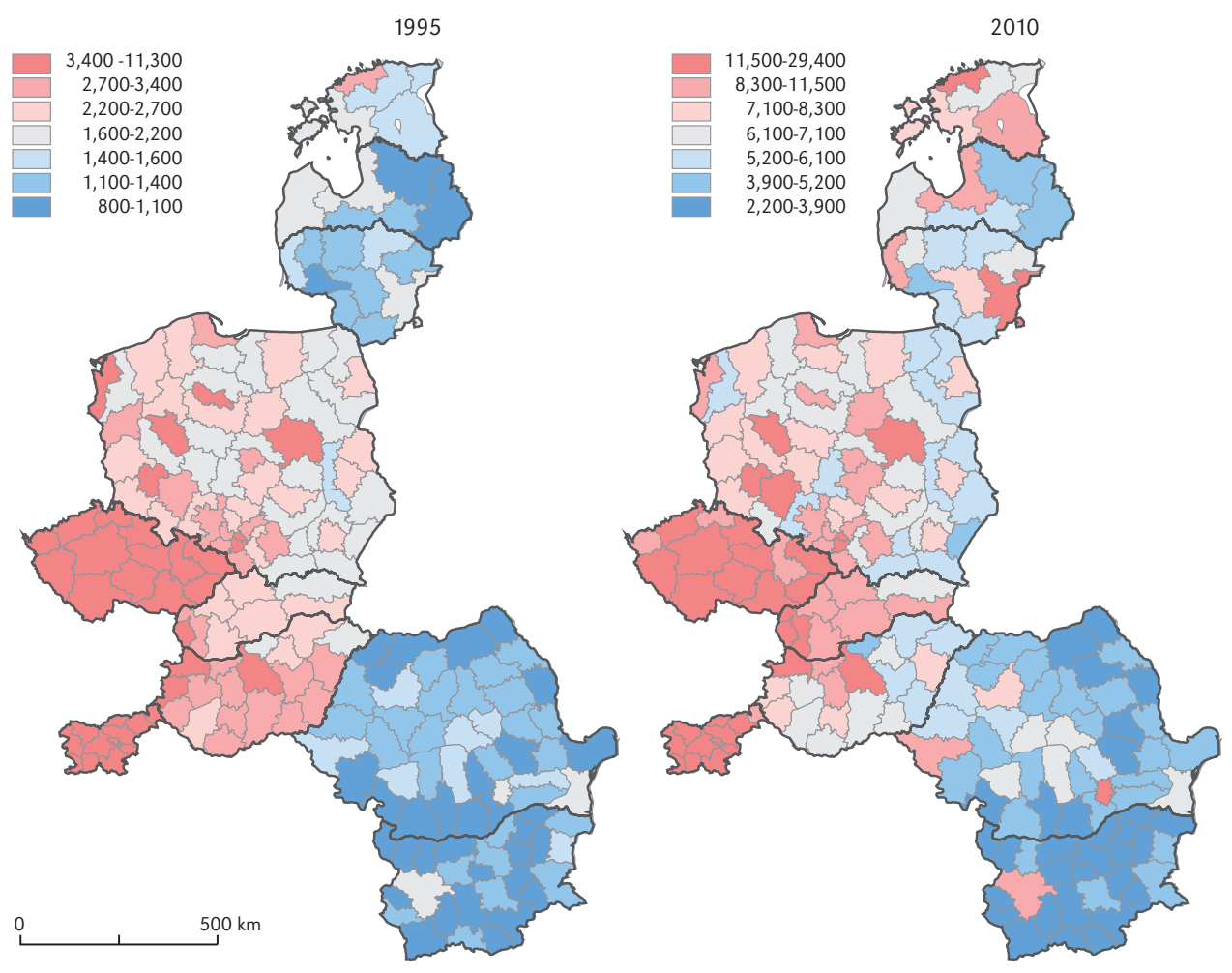

Figure 2. GDP per capita in EUR in the years 1995-2010*

* ranges based on the equal count method

Source: on the basis of Eurostat data and own estimations

Table 5. Different types of region based on local indicators of spatial association (LISA) in relation to GDP per capita in EUR in the years 1995-2010*

\begin{tabular}{|c|c|c|c|c|}
\hline Year & $\begin{array}{c}\text { HH - highly developed } \\
\text { region surrounded } \\
\text { by highly developed } \\
\text { regions }\end{array}$ & $\begin{array}{c}\mathrm{HL}-\text { 'hot spot' } \\
\text { highly developed region } \\
\text { surrounded by poorly } \\
\text { developed regions }\end{array}$ & $\begin{array}{c}\mathrm{LH}-\text { 'cold spot' } \\
\text { poorly developed region } \\
\text { surrounded by highly } \\
\text { developed regions }\end{array}$ & $\begin{array}{c}\mathrm{LL} \text { - poorly developed } \\
\text { region surrounded } \\
\text { by poorly developed } \\
\text { regions }\end{array}$ \\
\hline 1995 & 24 & - & - & 78 \\
2000 & 26 & 1 & - & 65 \\
2005 & 33 & 1 & 3 & 57 \\
\hline
\end{tabular}

* statistically significant at a level of 0.05

values for Moran's I statistic in the subsequent analysed periods, from 0.63 in the years $1995-2000$ to 0.21 in 2004-2008 (excluding the period of the crisis, 2008-2009). This indicates a weaker role of the regional surroundings in setting the pace of growth in a given region, which can in turn indicate hierarchical diffusion taking place across the macroregion. On the other hand, in the approach relativised to the national average, an opposite situation can be observed, i.e. an increased impact of external surroundings on the pace 
of growth of a given region, which could, however, point to contagious diffusion processes. This was largely a result of the emergence of the less-developing regions (especially in Romania and Bulgaria, but also in eastern Poland and Hungary) (Fig. 4). At the same time, the number of 'hot spots', i.e. metropolitan areas, was also growing (except in the crisis period) (Tab. 6), which could imply the existence of barriers to the contagious diffusion processes. In consequence, the concurrence of these phenomena can be viewed as proof of club convergence, whereby the rates of growth of the best-developed regions dispersed in space (metropolitan areas) and the less-developed regions (which form spatial clusters) become similar. This means that the former have a slight impact on their direct surroundings, attesting to the presence of barriers to the diffusion of development processes.

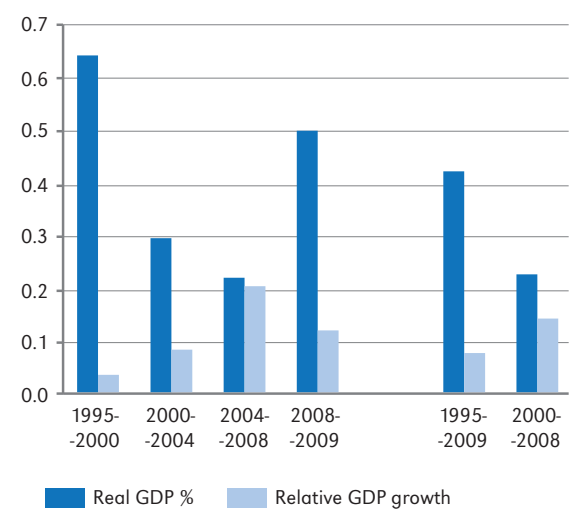

Figure 3. Global Moran's I statistic for GDP growth dynamics in absolute (\%) and relative terms (country average $=100$ )
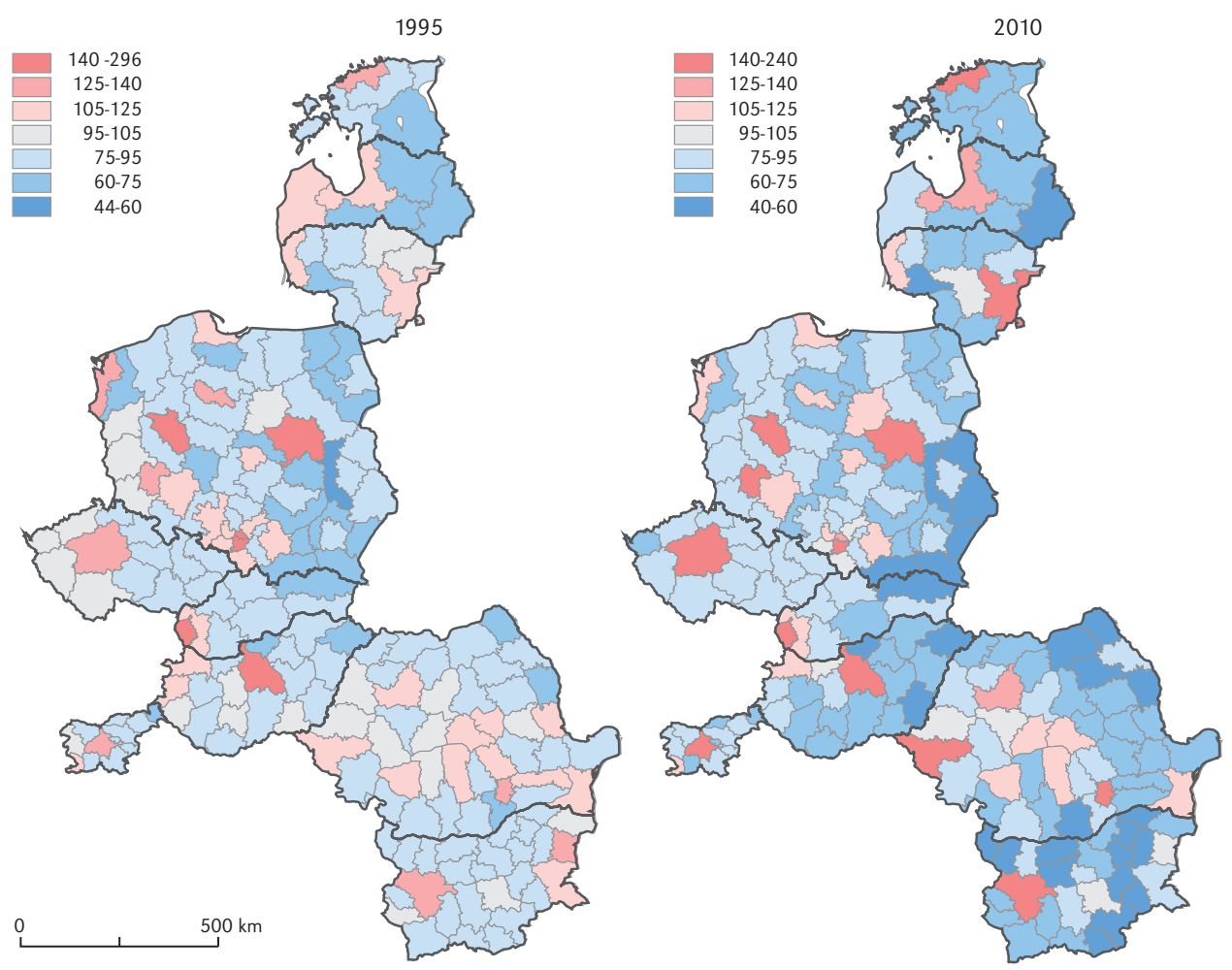

Figure. 4. GDP per capita [country average $=100$ ]

Source: on the basis of Eurostat data and own estimations 
Table 6. Different types of region based on local indicators of spatial association (LISA)

\begin{tabular}{|c|c|c|c|c|c|c|c|c|}
\hline \multirow{2}{*}{ Years } & \multicolumn{4}{|c|}{ GDP real growth (\%) } & \multicolumn{4}{|c|}{ GDP growth (country average=100) } \\
\cline { 2 - 9 } & $\mathrm{HH}$ & $\mathrm{HL}$ & $\mathrm{LH}$ & $\mathrm{LL}$ & $\mathrm{HH}$ & $\mathrm{HL}$ & $\mathrm{LH}$ & $\mathrm{LL}$ \\
\hline $1995-2000$ & 58 & 5 & 1 & 52 & 6 & 4 & 4 & 12 \\
$2000-2004$ & 22 & 4 & 3 & 20 & 6 & 7 & 5 & 11 \\
$2004-2008$ & 13 & 7 & 2 & 20 & 8 & 8 & 3 & 24 \\
$2008-2009$ & 47 & 6 & 6 & 28 & 7 & 3 & 4 & 13 \\
\hline
\end{tabular}

* statistically significant at a level of 0.05

\section{Diffusion of development in different sectors of the economy}

Diffusion processes can be expected to vary from one sector of the economy to another. The sectors should also appear diverse in terms of the scale of regional disparities measured for gross value added per capita. Advanced business services, industry and agriculture ${ }^{3}$ were selected for the analysis, in the order of the largest regional disparities. In the case of these sectors, various spatial trends could be observed in the years 19992010 (the period for which statistical data were available) (Fig. 5):

1. Advanced business services, with a rather stable scale of regional disparities, were also characterised by a sharp decrease in spatial autocorrelation. This can suggest that hierarchical diffusion is taking place, observable in ongoing metropolitanisation processes taking place in the less-developed countries, coupled with a growing role of metropolitan areas within the more-developed countries.

2. Industry, with a similar scale of regional disparities at the macroregional level as advanced business services, was nevertheless characterised by decreasing disparities, similarly to GDP per capita for both the

\footnotetext{
3 'Advanced business services' (NACE sections: $K$ - Financial and insurance activities; $L$ - Real estate activities; M - Professional, scientific and technical activities; N - Administrative and support service activities); 'Industry' (NACE sections: B - Mining and quarrying; C - Manufacturing; D - Electricity, gas, steam and airconditioning supply; E - Water supply; sewerage, waste management and remediation activities); 'Agriculture' - (NACE section: A - Agriculture, forestry and fishing).
}

coefficient of variation and Moran's I values. This indicates a mixed (contagious and hierarchical) type of diffusion in this sector, and suggests that the development of industrial activity played an important part in the convergence processes at macroregional level.

3. Agriculture was the only sector with slight regional divergence, accompanied by an increase in spatial dependency. This could point to the growing specialisation of agricultural regions, which tend to form larger macroregions.

The above conclusions are corroborated by cartographic analysis (Fig. 6). In the case of business services, the situation is varied within individual countries, with a tendency for the metropolitan areas of secondary non-capital cities to improve their position in this regard, a process especially well visible in Romania (Brașov, Cluj, Timișoara, Constanța and Alba lulia) and Hungary (Szeged and Debrecen), with these starting to resemble Poland, with its polycentric settlement system. In the case of industry, trends towards contagious diffusion were much more easily visible. In some countries, gradients to differences in the level of industrialisation either increased or remained stable, as was visible in Poland (south-west vs. north-east), Hungary (north-west vs. south and east) and Romania (west vs. east). In the case of agriculture, the situation was relatively stable, as associated with some of these regions continuing their specialisation (e.g. north-eastern and central Poland, southern Hungary and the Czech Republic), and relatively most varied in the longitudinal approach (particularly in Bulgaria). 


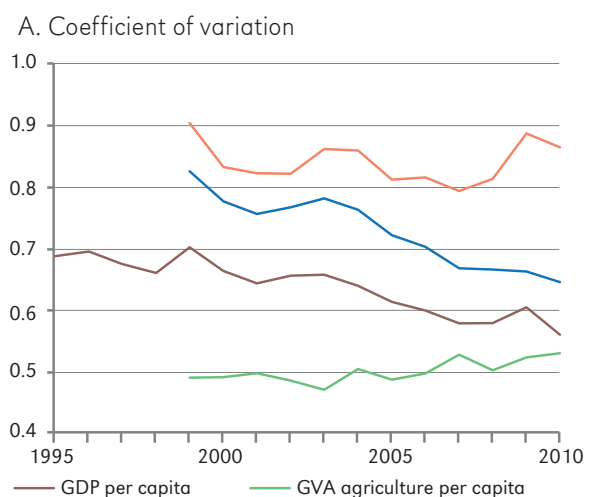

B. Global Moran's I statistics

Figure 5. Sigma convergence (A) and spatial dependency (B) of regional GDP per capita in EUR in the years 1995-2010, by sectors of the economy*

\section{Conclusions}

In the macroregional dimension, it is possible to observe gradual convergence of the poorer countries, which implies regional convergence (at NUTS3 level). The rate of regional growth measured in EUR in the CEECs is strongly dependent on the economic situation nationally, including changes in currency exchange rates. At the same time, if expressed in terms of real GDP growth in the national currency, this dependency is much weaker and varies from period to period. In some sub-periods (e.g. 1995-2000), the economic situation at country level affected growth rates of all regions very markedly, while in other periods (e.g. 2004-2008) it is possible to note considerable differences in the rates of growth of regional incomes that show little dependence on the overall economic situation domestically.

The scale of regional disparities in GDP per capita terms remain very large in the CEECs. In essence, the better-developed regions situated in the western part of the macroregion, and the poorer-developed sub-regions situated in the eastern part remain poles apart where levels of economic development are concerned. The observable diffusion processes assume a hierarchical form on the one hand, and comprise major cities situated in the less-developed coun- tries and areas. On the other hand, a moderate degree of contagious diffusion is to be observed, also in association with the existing major transport corridors.

The spread effects are manifested in reduced similarities in the growth rates of neighbouring regions across the macroregion, on the one hand, and on the other by increases similarities of this kind when the approach relativised to the national average is resorted to. Paradoxically, the latter may lead to an increase in the scale of regional divergence, as associated with the emergence of macroregions composed of sub-regions at a low level of development. In consequence, economic growth processes viewed spatially are rather 'patchy', revealing no distinct impact of the core regions on their immediate surroundings. In other words, it is possible to note examples of contagious diffusion, and examples of the lack thereof.

The types of diffusion were quite strongly dependent on the analysed sector of the economy. In the case of advanced services, there was a clear prevalence of hierarchical diffusion, which could mean that such services trickle down within the settlement system, in what would be a typical feature of contemporary metropolitanisation processes. The mixed hierarchical and contagious diffusion model was typically encountered in the industrial sector. Due to the fact that regional GDP performed in a similar way, this could 
GVA advanced

business services per capita

1999
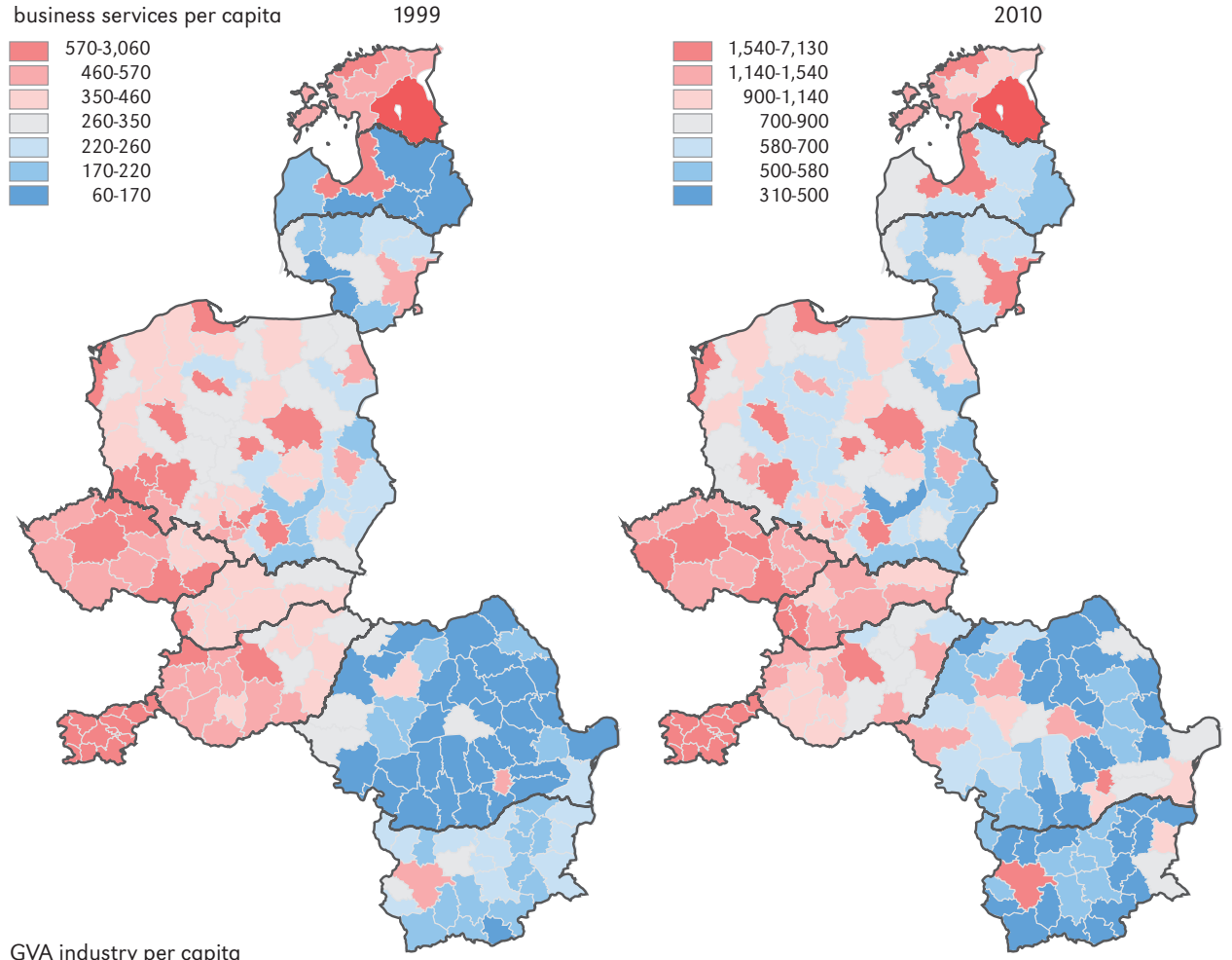

GVA industry per capita
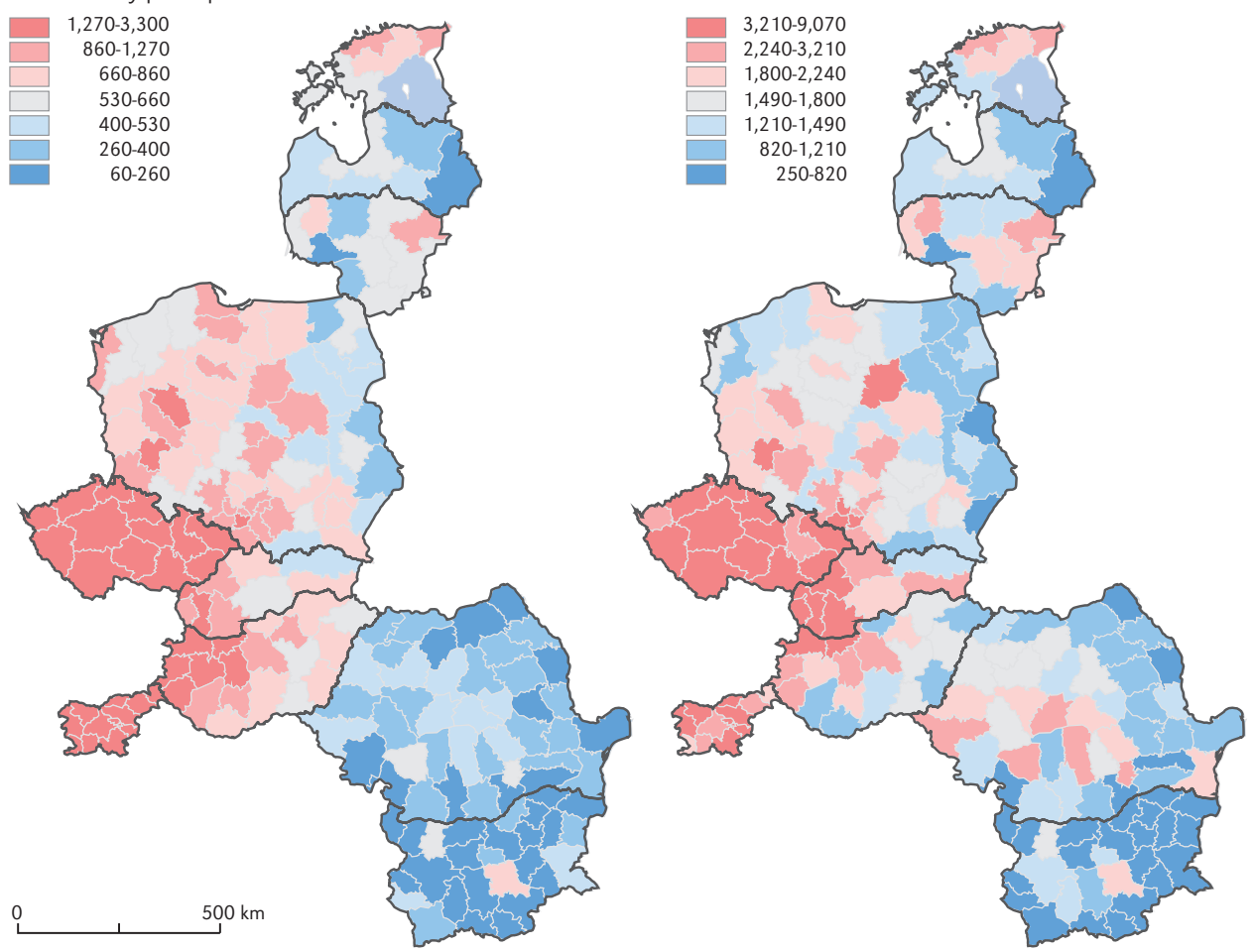

Figure 6. Gross Value Added (GVA) per capita in selected sectors in the years 1999-2010 ([in EUR] based on the equal counts method) 

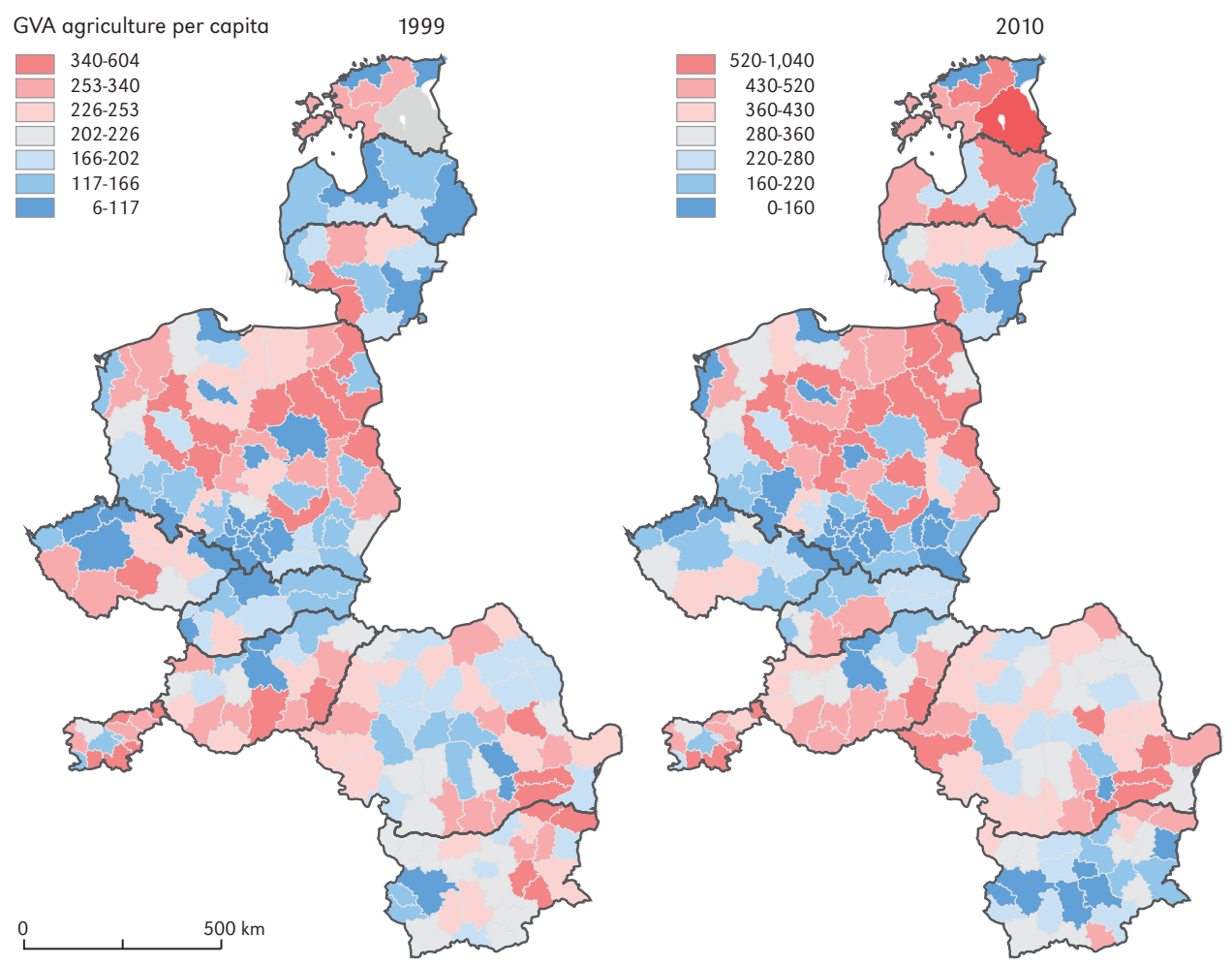

Figure 6. Gross Value Added (GVA) per capita in selected sectors in the years 1999-2010 ([in EUR] based on the equal counts method)

mean that industry played an important part in regional convergence processes at the macroregional level. In contrast, the situation in the agricultural sector was rather stable, with an observable tendency for specialisation to increase in certain regions situated in close proximity to one another.

The reasons for such a pattern can be traced first and foremost to the dominance of exogenous factors in the processes of regional development in the CEECs (Smętkowski 2013b). As a result, one could assume that foreign capital in the sector of advanced business services investing primarily in the capital cities is now expanding into secondary cities, as is manifested in hierarchical diffusion. In the case of the industrial sector, EU integration processes have combined with lower labour costs to encourage greater investor interest - except in the regions of large cities - in selected peripheral regions, especially those characterised by improved transport accessibility. The result has been a diverse hierarchical-contagious diffusion in this sector. In turn, the increasing specialisation of selected peripheral regions as regards agricultural production can be associated with the impact of the Common Agricultural Policy, whose support for agriculture can indirectly delay the process by which regional economies are restructured.

The spatial patterns of economic development in the CEECs should be similar in the future, as a result of a diffusion process assuming the forms indicated above. Petrification of regional disparities is to be expected where these depend more on growth dynamics at national level than on processes taking place at regional level. This poses a significant 
challenge for regional policy, which should focus to greater extent than now on the promotion of development at national level, with less of a focus than hitherto on assistance for less-developed areas. This does not mean that the latter should be abandoned by regional policy, but it does mean that actions concerning them should support their restructuring process and efforts to achieve functional cohesion between core and less-developed areas. In particular, it may take the form of a strengthening of the major urban centres in less-developed regions, so that these may play the role of local growth poles.

\section{References}

BACHTLER J., DOWnes R., 2004. Enlargement and EU regional policy [in:] H. Karl, P. Rollet (eds.), Employment and regional development policy: Market policy versus policy interventions, Hannover: Akademie für Raumforschung und Landesplanung.

Bachtler J., McMaster I., 2008. EU Cohesion policy and the role of the regions: Investigating the influence of structural funds in the new member states. Environment and Planning C: Government and Policy, vol. 26, no. 2, pp. 398427.

CURRAN D., 2009. British regional growth and sectoral trends: Global and local spatial econometric approaches, NIRSA Working Paper Series, no. 49, Maynooth: National Institute for Regional and Spatial Analysis.

ESPON 1.1.3, 2005. Enlargement of the European Union and the wider European perspective as regards its polycentric spatial structure. Stockholm: The Royal Institute of Technology.

Ezcurra R., Pascual P., Rapu M., 2007. The dynamics of regional disparities in Central and Eastern Europe during transition. European Planning Studies, vol. 15, no. 10, pp. 1397-1421.

FLORIDA R., 2002. The rise of the creative class: And how It's transforming work, leisure, community and everyday life. New York: Basic Books.

GoRZELAK G., 2008. Development of Polish regions and the EU cohesion policy [in:] W. Strubelt,

\section{Acknowledgements}

The research leading to these results has received funding from the European Union's Seventh Framework Programme (FP7/20072013) under the "Growth-Innovation-Competitiveness: Fostering Cohesion in Central and Eastern Europe" (GRINCOH) grant agreement.

Editors' note:

Unless otherwise stated, the sources of tables and figures are the author's, on the basis of their own research.

G. Gorzelak (eds.), City and region: Papers in honour of Jiri Musil, Leverkusen Opladen, Farmington Hills: Budrach UniPress Ltd, pp. 97-120.

GorzelaK G., JatowieCKI B., 2002. European boundaries: Unity or division of the continent? Regional Studies, vol. 36, no. 4, pp. 409-419.

GorzelaK G., 2009. Cohesion and convergence: Synonyms or two different notions [in:] G. Kochendörfer-Lucius, B. Pleskovic (eds.), Spatial disparities and development policy, Washington, DC: The World Bank, pp. 259-264.

Gorzelak G., SMęTKOWSKı M., 2010. Regional development dynamics in Central and Eastern European countries [in:] G. Gorzelak, J. Bachtler, M. Smętkowski (eds.), Regional development in Central and Eastern Europe: Development processes and policy challenges, New York: Routledge, pp. 34-58.

Gould P.R., 1969. Spatial diffusion. Resource Paper, no. 4, Washington: Association of American Geographers.

GrzeszczaK J., 1999. Bieguny wzrostu a formy przestrzeni spolaryzowanej. Prace Geograficzne, 173, Wrocław-Warszawa: Continuo, Instytut Geografii i Przestrzennego Zagospodarowania PAN.

HÄGERSTRAND T., 1952. The propagation of innovation waves. Lund Studies in Geography. Ser. B. Human Geography, 4, Lund: The Royal University of Lund, pp. 3-19. 
HägeRSTRAND T., 1967. Innovation diffusion as a spatial process. Chicago: The University of Chicago Press.

HILPERT U., 1992. Archipelago Europe: Islands of innovation. Forecasting and Assessment in Science, vol. 18, Brussels: FAST, Commission of the European Communities.

HIRSCHMAN A.O., 1958. The strategy of economic development. New Haven: Yale University Press.

JANC K., 2006. Zjawisko autokorelacji przestrzennej na przykładzie statystyki I Morana oraz lokalnych wskaźników zależności przestrzennej (LISA) - wybrane zagadnienia metodyczne [in]: T. Komorowski, Z. Podgórski (eds.), Idee praktyczne i uniwersalizm geografii, Dokumentacja Geograficzna, 33. Warszawa: Instytut Geografii i Przestrzennego Zagospodarowania PAN.

Kołodko G., Tomkiewicz J. (eds.), 2009. 20 lat transformacji. Osiagnięcia, problemy, perspektywy, Warszawa: Wydawnictwa Akademickie i Profesjonalne.

KopCZEWSKA K., 2006. Ekonometria i statystyka przestrzenna z wykorzystaniem programu R CRAN. Warszawa: CeDeWu.

KRUGMAN P., 1991. Increasing returns and economic geography. Journal of Political Economy, vol. 99, no. 3, pp. 483-499.

ŁOBODA J., 1983. Rozwój koncepcji i modeli przestrzennej dyfuzji innowacji. Acta Universitatis Wratislaviensis, 585, Studia Geograficzne, 37, Wrocław: Wydawnictwo Uniwersytetu Wrocławskiego.

MonastiRIOTIS V., 2011. Regional growth dynamics in Central and Eastern Europe. LSE 'Europe in Question' discussion paper series, 33/2011. London: The London School of Economics and Political Science.

MORILL R., 1968. Waves of spatial diffusion. Journal of Regional Science, vol. 8, no. 1, pp. 1-18.

MYRDAL G., 1957. Economic theory and underdevelopment regions. London: Duckworth.

NorTH D.C., 1991. Institutions. The Journal of Economic Perspectives, vol. 5, no. 1, pp. 97-112.

OECD, 2010. Regional Development Policies in OECD Countries. Paris: OECD Publishing.
Perroux F., 1950. Economic space: Theory and applications. The Quarterly Journal of Economics, vol. 64, no. 1, pp. 89-104.

Petrakos G., 2001. Patterns of regional inequality in transition economies. European Planning Studies vol. 9, no. 3, pp. 359-383.

PróChniak M., 2011. Determinants of economic growth in Central and Eastern Europe: The global crisis perspective. Post-Communist Economies, vol. 23, no. 4, pp. 449-468.

Rey S.J., Montourl B.D., 1999. US regional income convergence: A spatial econometric perspective. Regional Studies, vol. 33, no. 2, pp. 143-156.

Ressende G.M., 2012. Essays on spatial scope of regional economic development in Brazil. The London School of Economics and Political Science [PhD thesis].

RöMICH R., 2003. Regional disparities within accession countries [in:] G. Tumpel-Gugerell, P. Mooslechner (eds.), Economic convergence and divergence in Europe: Growth and regional development in an enlarged European Union, Cheltenham: Edward Elgar, p. 183.

Sala-I-Martin X., 1996. The classical approach to convergence analysis. The Economic Journal, vol. 106, no. 437, pp. 1019-1036.

SMĘTKOWSKI M., Wóscik P., 2012. Regional convergence in Central and Eastern European countries - a multidimensional approach. European Planning Studies, vol. 20, no. 6, pp. 923-939.

SMETKOWSKI M., 2013a. Regional disparities in Central and Eastern Europe: Trends, drivers and prospects. Europe-Asia Studies, vol. 65, no. 8, pp. 1529-1554.

SMĘTKOWSKI M., 2013b. Rozwój regionów i polityka regionalne w krajach Europy Środkowo-Wschodniej w okresie transformacji i globalizacji. Warszawa: Wydawnictwo Naukowe Scholar.

StORPER M., 1997. The regional world: Territorial development in a global economy. New York: The Guilford Press.

VERNON R., 1966. International investment and international trade in the product cycle. Quarterly Journal Economics, vol. 80, no. 2, pp. 190-207. 
http://rcin.org.pl 